\title{
Editorial
}

\section{Gene Therapy: A New Challenge for Infection Control}

\author{
David J. Weber, MD, MPH; William A. Rutala, PhD, MPH
}

Advances in biotechnology present infection control professionals with new challenges, including gene therapy, xenotransplantation, and bioterrorism. Recent reviews have summarized the infectious risks, including the risk of human-to-human transmission, associated with xenotransplantation $^{1-6}$ and bioterrorism. ${ }^{7-11}$ Federal agencies have recognized the infectious threats posed by xenotransplantation and bioterrorism, and they and others have published draft guidelines on infectious disease issues in xenotransplantation, ${ }^{12}$ interim guidelines for the management of anthrax, ${ }^{13}$ and guidelines for anthrax, botulism, plague, and smallpox when used for bioterrorism. ${ }^{14}$ However, few reviews of the nosocomial risk posed by gene therapy have been published. ${ }^{15}$

The last decade has seen a dramatic increase in the number of gene-therapy protocols being conducted in the United States and around the world. The first gene-therapy protocol in the United States was initiated in 1990 for the treatment of severe combined immunodeficiency. ${ }^{16}$ As of March 1, 1999, 373 gene-therapy protocols had enrolled 3,134 patients worldwide. ${ }^{17}$ Of these, 278 protocols $(74.5 \%)$ involving 2,200 patients $(70.2 \%)$ have been approved in the United States. The 373 protocols worldwide include 245 phase I trials, 93 phase I/II trials, 33 phase II trials, and 2 phase III trials. More than $60 \%$ of gene-therapy protocols are aimed at cancer therapy, but other common uses include gene marking and therapy of monogenic or infectious diseases. The proliferation of clinical gene-therapy trials reflects our developing understanding of the genetic bases of many diseases and rapid advances in molecular biology, including the ability to produce vectors capable of transferring genetic material into somatic cells.

Understanding the methodology of gene therapy is crucial to understanding the nosocomial risks posed by gene therapy and to developing rational infection control guidelines. There are two main approaches to gene therapy: in vivo gene therapy, in which genes are delivered directly to target cells in the body, and ex vivo gene therapy, in which target cells are genetically manipulated outside the body and then reimplanted. ${ }^{18}$ To carry out gene therapy, the exogenous gene(s) is transferred in an expression cassette, including the promoter that regulates expression of the new gene (often in the form of a cDNA) and stop signals to terminate translation. ${ }^{19}$ The exogenous or therapeutic gene can be isolated from the genome of a human, another animal, a plant, a bacterium, or a virus and may code for any type of protein. ${ }^{18}$ Depending on the choice of the regulatory element that controls the expression of the therapeutic gene, gene expression can be high- or low-level, specific to certain cell types, or even continuously variable, and can respond to local environmental factors such as the partial pressure of oxygen or the concentration of a drug. 18

The expression cassette is transferred to target cells using a "vector." Each delivers the expression cassette via distinct mechanisms, and each has its own unique advantages and disadvantages. The most commonly used vector systems include retroviruses, adenoviruses, and poxviruses. Other viral vectors include adeno-associated virus, herpes viruses, and lentiviruses. Although viral vectors have been most commonly used, nonviral vector systems are of increasing scientific interest. Nonviral vector systems include plasmidliposome complexes, newer kinds of vectors that sheath DNA in nonlipid coats, and "naked" DNA. ${ }^{2022}$

In this issue, Evans and Lesnaw provide an excellent review of potential infectious hazards associated with gene therapy and provide guidance for institutions to develop appropriate infection control policies. ${ }^{23}$ Ex vivo gene therapy presents a risk only to laboratory personnel producing the vectors and to clinical personnel actually manipulating the patient's blood or tissue ex vivo. Adherence to recommended laboratory practices ${ }^{24}$ and to Standard Precautions ${ }^{25}$ should minimize any risk. Guidelines also are available from the

From the Division of Infectious Diseases, University of North Carolina School of Medicine, and the Department of Hospital Epidemiology, University of North Carolina Health Care System, Chapel Hill, North Carolina.

Address reprint requests to David Jay Weber, MD, MPH, 547 Burnett-Womack, CB \#7030, Division of Infectious Diseases, UNC at Chapel Hill, Chapel Hill, NC 27599-7030.

99-ED-055. Weber DJ, Rutala WA. Gene therapy: a new challenge for infection control. Infect Control Hosp Epidemiol 1999;20:530-532. 
TABLE

INFECTION CONTROL RECOMMENDATIONS BASED ON TRANSMISSION VECTOR

\begin{tabular}{|c|c|c|c|c|}
\hline Vector & $\begin{array}{l}\text { Protocols } \\
\text { (Patlents)* }\end{array}$ & $\begin{array}{l}\text { Potential } \\
\text { Advantages }{ }^{\dagger}\end{array}$ & $\begin{array}{l}\text { Potentlal } \\
\text { Drawbacks }{ }^{\dagger}\end{array}$ & $\begin{array}{l}\text { Infectlon } \\
\text { Control Concerns }\end{array}$ \\
\hline Retroviruses & $41.3 \%(38.1 \%)$ & $\begin{array}{l}\text { High efficiency; potential for } \\
\text { stable integration into host } \\
\text { chromosome; amphotropic } \\
\text { viruses for a wide variety of } \\
\text { tissues }\end{array}$ & $\begin{array}{l}\text { Genes integrate randomly, so } \\
\text { might disrupt host genes; many } \\
\text { infect only dividing cells; limited } \\
\text { size }\end{array}$ & $\begin{array}{l}\text { Minimal hazard when they are } \\
\text { incubated with host cells ex vivo; } \\
\text { secondary infections via accidental } \\
\text { inoculation or sexual transmission } \\
\text { possible if agent acquires replica- } \\
\text { tion competence; use Standard } \\
\text { Precautions }\end{array}$ \\
\hline Adenoviruses & $16.9 \%(11.6 \%)$ & $\begin{array}{l}\text { Most do not cause serious } \\
\text { disease; high production; extra- } \\
\text { chromosomal, avoiding altera- } \\
\text { tions; large capacity for foreign } \\
\text { genes and great stability }\end{array}$ & $\begin{array}{l}\text { Genes may function transiently, } \\
\text { owing to lack of integration or } \\
\text { attack by the immune system; } \\
\text { systemic infections possible }\end{array}$ & $\begin{array}{l}\text { Persistent in the environment; need } \\
\text { to disinfect contaminated environ- } \\
\text { mental objects appropriately; trans- } \\
\text { mittable via fomites, close personal } \\
\text { contact, or droplets; hand washing } \\
\text { with soap and water may not be } \\
\text { effective }\end{array}$ \\
\hline Adeno-associated viruses & $0 \% \quad(1.1 \%)$ & $\begin{array}{l}\text { Integrate genes into host } \\
\text { chromosomes; cause no known } \\
\text { human diseases }\end{array}$ & $\begin{array}{l}\text { Small capacity for foreign } \\
\text { genes }\end{array}$ & $\begin{array}{l}\text { Prudent to use same precautions } \\
\text { as for adenoviruses }\end{array}$ \\
\hline Herpesvirus & $0.3 \%(0 \%)$ & $\begin{array}{l}\text { Produced at high levels; targets } \\
\text { nondividing nerve cells }\end{array}$ & $\begin{array}{l}\text { Hard to produce; viral gene } \\
\text { required }\end{array}$ & $\begin{array}{l}\text { Person-to-person transmission via } \\
\text { close contact if skin lesions pre- } \\
\text { sent; latency; use Standard (limit- } \\
\text { ed diseases) or Contact Pre- } \\
\text { cautions (disseminated disease) }\end{array}$ \\
\hline Liposomes & $18.5 \%(23.1 \%)$ & $\begin{array}{l}\text { Have no viral genes, so do not } \\
\text { cause disease; simple to use } \\
\text { and prepare; use of any DNA } \\
\text { and RNA, no limit to size }\end{array}$ & $\begin{array}{l}\text { Less efficient than viruses at } \\
\text { transferring genes to cells }\end{array}$ & No infection control implications \\
\hline "Naked" DNA & $3.5 \%(2.2 \%)$ & $\begin{array}{l}\text { Same as for liposomes; expected } \\
\text { to be useful for vaccination }\end{array}$ & $\begin{array}{l}\text { Inefficient at gene transfer; } \\
\text { unstable in most body tissues }\end{array}$ & No infection control implications \\
\hline
\end{tabular}

National Institutes of Health (NIH) for research involving recombinant DNA molecules ${ }^{26}$ and from the Food and Drug Administration for human somatic cell therapy and gene therapy. ${ }^{27}$ Nevertheless, institutions in which ex vivo gene therapy is being conducted should have protocols for managing personnel with accidental exposure (typically via a percutaneous injury) to the vector being used.

The infectious hazard associated with in vivo gene therapy is transmission of the vector to hospital personnel, other patients, and visitors. Following hospital discharge, and depending on the vector, treated patients may be capable of transmitting the vector to family, friends, and other contacts. The NIH requires persons submitting gene-therapy protocols to describe the hazards the proposed therapy poses to persons other than the patients being treated. ${ }^{26}$ First, the investigator must describe on what basis are potential public health benefits or hazards postulated? Second, is there a significant possibility that the added DNA will spread from the patient to other persons or the environment? Third, what precautions will be taken against such spread (eg, patient sharing a room, healthcare workers, or family members)? Fourth, what measures will be undertaken to mitigate the risks, if any, to public health? Fifth, in light of possible risks to offspring, including vertical transmission, will birth control measures be recommended to patients? Finally, are such concerns applicable to healthcare personnel? Despite the proliferation of gene-therapy protocols, limited guidance regarding the magnitude of risk or strategies to prevent risk is available for several reasons. First, NIH guidelines on gene therapy do not discuss how to assess the level of risk, what level of risk is acceptable, or measures to minimize such risks. Second, there are currently no NIH, Food and Drug Administration, or Centers for Disease Control and Prevention (CDC) infection control guidelines for minimizing the hazards to healthcare personnel caring for patients on gene-therapy protocols or for preventing person-to-person transmission of gene-therapy vectors. Finally, few scientific studies regarding environmental isolation and survival of expression vectors or risks of transmission to contacts of treated patients have been published.

Evans and Lesnaw propose basing infection control strategies on the type of vector used for gene therapy..$^{23}$ This approach is to be applauded and provides a rational way of understanding the risks posed by gene-therapy vectors and 
simplifying isolation guidelines. We have taken the liberty of summarizing many of their recommendations (Table). ${ }^{17,20,23,28,29}$ Replication-deficient vectors or noninfectious vectors should pose minimal risk to the contact of treated patients, including healthcare personnel. A higher risk of transmission would occur with replication-competent vectors, especially those that may become latent and later reactivate (eg, herpesvirus). Other risk factors for transmission would include the method of vector administration, mechanism of natural transmission of the vector, infectivity of the vector, and ability of the vector to survive in the environment. Routes of administration of current vectors most commonly pose a risk to healthcare personnel in the event of sharp injury and include the following routes (\% of protocols): intratumor $(28.7 \%)$, intravenous (17.2\%), subcutaneous $(14.2 \%)$, via bone marrow transplantation $(11.0 \%)$, and intradermal (4.8\%). ${ }^{17}$ Vectors also have been administered by the intranasal (5.4\%) and intrabronchial (1.6\%) routes, which raise the possibility of aerosol transmission to healthcare workers and other contacts. Vectors that result in respiratory tract infection, such as adenoviruses, also raise concern about droplet transmission. If vectors such as herpesviruses and vaccinia virus result in cutaneous or mucous membrane lesions, they could be transmitted via direct contact with skin or mucous membranes. Finally, Evans and Lesnaw note that some viruses used as vectors, such as adenovirus, can survive for an extended period of time in the environment and may survive superficial disinfection such as wiping instruments with alcohol. Furthermore, multiple outbreaks of epidemic keratoconjunctivitis have incriminated contaminated fomites. ${ }^{30}$

Additional research is required to assess the risk associated with gene therapy and to develop validated protocols to prevent transmission of vectors. Specific studies should be undertaken to assess the following, especially for replication-competent vectors or those capable of becoming latent: (1) rates of transmission to healthcare providers, other patients, visitors, and postdischarge contact; (2) likelihood of environmental isolation and duration of survival of the vector, especially for vectors transmitted by droplet or contact spread; and (3) means of disinfecting surfaces contaminated by agents used as vectors. Only limited data are available regarding the efficacy of eliminating adenovirus from instruments. The ability of disinfectants to inactivate viruses mixed with blood is dramatically reduced compared to viruses suspended in saline..$^{31}$

The CDC and the NIH should assess the risks posed by gene therapy and provide guidelines for reducing nosocomial risks. Furthermore, the NIH should consider requiring investigators to evaluate contact for the possibility of vector transmission and develop a registry of cases of transmission. Gene therapy has the potential to provide tremendous benefits, but the risks must be further delineated.

\section{REFERENCES}

1. Fishman JA. Xenosis and xenotransplantation: addressing the infectious risks posed by an emerging technology. Kidney Int Suppl 1997;58:S41-S45.

2. Michaels MG. Infectious concerns of cross-species transplantation: xenozoonoses. World J Surg 1997;21:968-974.

3. Patience C, Takeuchi Y, Weiss RA. Zoonosis in xenotransplantation. Curr Opin Immunol 1998;10:539-542.

4. Fishman JA. The risk of infection in xenotransplantation. Ann NY Acad Sci 1998;862:45-51.

5. Borie DC, Cramer DV, Phan-Thanh I, Vaillant JC, Bequet JL, Makowka L, et al. Microbiological hazards related to xenotransplantation of porcine organs into man. Infect Control Hosp Epidemiol 1998;19:355-365.

6. Allan JS. The risk of using baboons as transplant donors. Ann NY Acad Sci 1998;862:87-99.

7. Simon JD. Biological terrorism. JAMA 1997;278:428-430.

8. Carus WS. Biological warfare threats in perspective. Crit Rev Micriobiol 1998;24:149-155.

9. Christopher GW, Cieslak TJ, Pavlin JA, Eitzen EM. Biological warfare: a historical perspective. JAMA 1997;278:412-417.

10. Franz DR, Jahrling PB, Friedlander AM, McClain DJ, Hoover DL, Bryne WR, et al. Clinical recognition and management of patients exposed to biological warfare agents. JAMA 1997;278:399-411.

11. Atlas RM. The medical threat of biological weapons. Crit Rev Microbiol 1998:24:157-168

12. Public Health Service. Draft public health service guideline on infectious disease issues in xenotransplantation. Federal Register September 23, 1996;61:49920-49932.

13. Centers for Disease Control and Prevention. Bioterrorism alleging use of anthrax and interim guidelines for management-United States, 1998. MMWR 1999;48:69-74.

14. English JF, Cundiff MY, Malone JD, Pfeiffer JA, Bell M, Steele L, et al. Bioterrorism readiness plan: a template for healthcare facilities. http://www.apic.org/html/educ/readinow.html.

15. Weber DJ, Hoffmann KK, Rutala WA. Infection control in gene therapy. In: Mayhall GG, ed. Hospital Epidemiology and Infection Control. Baltimore, MD: Williams \& Wilkins; 1996:794-797.

16. Blaese RM, Culver KW, Miller AD, Carter CS, Fleisher T, Clerici M, et al. T lymphocyte-directed gene therapy for ADA sup minus SCID: initial trial results after 4 years. Science 1995;270:465-480.

17. The Journal of Gene Medicine Website. The Clinical Trials Website. http://www.wiley.co.uk/genmed.

18. Russell SJ. Science, medicine, and the future: gene therapy. $B M J$ 1997;315:1289-1292.

19. Feuerbach FJ, Crystal RG. Progress in human gene therapy. Kidney Int 1996;49:1791-1794.

20. Friedmann T. Overcoming the obstacles to gene therapy. Sci Am 1997;276:96-101.

21. Felgner PL. Nonviral strategies for gene therapy. Sci Am 1997;276:102-106.

22. Wivel NA, Wilson JM. Methods of gene delivery. Hematol Oncol Clin North Am 1998;12:483-501.

23. Evans ME, Lesnaw JA. Infection control in gene therapy. Infect Control Hosp Epidemiol 1999;20:568-576.

24. US Department of Health and Human Services. Biosafety in Microbiology and Biomedical Laboratories. 3rd ed. Washington, DC: US Government Printing Office; 1993.

25. Occupational Safety and Health Administration. Occupational exposure to bloodborne pathogens. Federal Register December 6, 1991;56:6417564182 .

26. National Institutes for Health. Guidelines for research involving recombinant DNA molecules (NIH guidelines), May 1998. www.nih. gov/od/orda/toc.htm.

27. Center for Biologics Evaluation and Research, Food and Drug Administration. Guidance for human somatic cell therapy and gene therapy, March 1998. Human Gene Therapy 1998;9:1513-1524 (also www.fda.gov/cber/guidelines.htm)

28. Duque MDPM, Sanchez-Preito R, Lieonart M, Cajal SRY. Perspectives in gene therapy. Histol Histopathol 1998;13:231-242.

29. Kmiec EB. Gene therapy. American Scientist 1999;87:240-247.

30. Weber DJ, Durand M, Rutala WA. Nosocomial ocular infections. In; Mayhall GG, ed. Hospital Epidemiology and Infection Control. 2nd ed. Baltimore, MD: Williams \& Wilkins. In press.

31. Weber DJ, Barbee SL, Sobsey MD, Rutala WA. The effect of blood on the antiviral activity of sodium hypochlorite, a phenolic, and a quaternary ammonium compound. Infect Control Hosp Epidemiol 1999. In press. 